\title{
Peripheral antinociception and anti-edematogenic effect of a sulfated polysaccharide from Acanthophora muscoides
}

\author{
Ana L. G. Quinderé ${ }^{1}$, Bruno P. Fontes ${ }^{1}$, Edfranck de S. O. Vanderlei ${ }^{1}$, \\ Ismael N.L. de Queiroz ${ }^{1}$, José A. G. Rodrigues ${ }^{1}$, Ianna W. F. de Araújo ${ }^{1}$, \\ Roberta J. B. Jorge ${ }^{2}$, Dalgimar B. de Menezes ${ }^{3}$, Antonio A. R. e Silva ${ }^{4}$, \\ Hellíada V. Chaves ${ }^{4}$, Janaina S. A. M. Evangelista ${ }^{5}$, Mirna M. Bezerra6 ${ }^{6}$, \\ Norma M. B. Benevides ${ }^{1}$ \footnotetext{
Zip Code: 60455-760, Fortaleza, Brazil

${ }^{2}$ Department of Physiology and Pharmacology, Federal University of Ceará, Avenida Coronel Nunes de Melo, 1127, Zip Code: 60430-270, Fortaleza, Brazil

${ }^{3}$ Department of Pathology and Forensic Medicine, Federal University of Ceará, Rua Monsenhor Furtado, s/n, Zip Code: 60441-750, Fortaleza, Brazil

${ }^{4}$ Faculty of Dentistry, Federal University of Ceará, Rua Comandante Maurocélio Rocha Ponte, 100, Zip Code: 62042-280, Sobral, Brazil

${ }^{5}$ Faculty of Veterinary Medicine, State University of Ceará, Avenida Paranjana, 1700, Zip Code: 60740-903, Fortaleza, Brazil

${ }^{6}$ Faculty of Medicine, Federal University of Ceará, Rua Comandante Maurocélio Rocha Ponte, 100, Zip Code:
} \\ ${ }^{1}$ Department of Biochemistry and Molecular Biology, Federal University of Ceará, Avenida Humberto Monte, s/n, \\ 62042-280, Sobral, Brazil
}

Correspondence: Norma M. B. Benevides, e-mail: nmbb@ufc.br

\begin{abstract}
:
Background: Sulfated polysaccharides from red marine algae have presented a variety of potentially therapeutic biological effects, however, their antinocicpetive and anti-inflammatory properties are not well understood.

Methods: Male Swiss mice were pretreated with a sulfated polysaccharidic fraction obtained from the marine alga Acanthophora muscoides (AmII) $(1,3$ or $9 \mathrm{mg} / \mathrm{kg}$, iv) 30 min prior to either receiving an injection of $0.8 \%$ acetic acid or $1 \%$ formalin or prior to a thermal stimulus. AmII (1, 3 or $9 \mathrm{mg} / \mathrm{kg}, s c)$ was evaluated on carrageenan-, dextran- bradykinin-, histamine- and serotonininduced rat paw edema models. AmII $(500 \mu \mathrm{g}, s c)$ was also injected into the paw. Additionally, mice were treated with the total sulfated polysaccharides from $A$. muscoides (Am-TSP) $(20 \mathrm{mg} / \mathrm{kg}$, ip ) for 14 days.

Results: AmII reduced the number of acetic acid-induced writhes and licking time in the second phase of the formalin test, but it did not alter the response latency in the hot plate test, suggesting that its antinociceptive action occurs through a peripheral mechanism. AmII did not reduce carrageenan-induced paw edema and MPO activity. However, it reduced dextran-, histamine- and serotonin- induced paw edemas, but not bradykinin-induced edema, suggesting that histamine is the major target of AmII anti-edematogenic activity. AmII injected into the paw did not evoke local edema. Furthermore, Am-TSP induced no consistent signs of systemic damage, as revealed by body mass, organs wet weight and by biochemical, hematological and histopathological analyses.

Conclusion: AmII has important antinociceptive and anti-inflammatory properties and represents an important therapeutic agent warranting future studies.
\end{abstract}

Key words:

marine alga, sulfated polysaccharide, nociception, inflammation 


\section{Introduction}

Pain can be simply defined as undesirable physical or emotional experiences which represents the most common reason why individuals seek medical attention [26]. In addition, the inflammatory process is a complex series of cellular and biochemical events that has evolved to eliminate or contain infectious agents and to repair damaged tissue. An ineffective or uncontrolled inflammatory response contributes to the cellular dysfunction, tissue damage and inadequate repair that occur in many chronic inflammatory diseases [18].

The side effects of the medications currently used to limit the extent of pain and inflammation vary based on the class of agent used, however, most medical personnel are concerned with addiction, tolerance, gastrointestinal effects and abuse [26]. Therefore, animal models of nociception are widely used as screening tools for the development of new analgesic drugs [21].

Marine organisms are sources of structurally diverse bioactive compounds with valuable pharmaceutical and biomedical potentials [11, 46, 49]. Marine algae are the most important source of non-animal sulfated polysaccharides, and the chemical structure of these polymers varies according to the algal species [32].

In recent years, sulfated polysaccharides from red marine algae have been shown to have a variety of potentially therapeutic biological effects, such as anticoagulant [28, 37], antithrombotic [16], antioxidant [6, 41], antiviral [49], antitumoral and immunomodulatory effects [22]. However, there are a fewer number of reports on antinociceptive and/or anti-inflammatory activities of sulfated polysaccharides obtained from marine algae $[1,2,7,43,45,46]$. To the best of our knowledge, there are no reports concerning the biological activities of sulfated polysaccharides from the red marine alga Acanthophora muscoides (Linnaeus) Bory de Saint-Vincent (Rhodomelaceae).

The purpose of the present study was to investigate the antinociceptive and anti-inflammatory activities of a sulfated polysaccharidic fraction from the alga A. muscoides using experimental models. The safety of the sulfated polysaccharides was also assessed.

\section{Materials and Methods}

\section{Animals}

Male and female Swiss mice (20-25 g) and male Wistar rats (160-220 g) from the Animal Care Unit of the Fed- eral University of Ceará, Fortaleza, Brazil, were used throughout the experiments. They were housed in a temperature-controlled room $\left(20-22^{\circ} \mathrm{C}\right)$ with free access to water and food on a 12/12 h light/dark cycle and special care was taken to avoid environmental disturbances that might influence animal responses. For each experiment, groups of six animals were segregated and handled separately. This study was conducted in accordance with the guidelines set forth by the U.S. Department of Health and Human Services, and with the approval of the Ethics Committee of the Federal University of Ceará, Fortaleza, Brazil (CEPA no. 80/10).

\section{Drugs and reagents}

The following drugs and reagents were used: dextran sulfate, $\lambda$-carrageenan, histamine, serotonin, bradykinin, cetylpyridinium chloride (CPC), 1,9-dimethylmethylene blue (DMB), indomethacin, agarose gel, 1,3-diaminopropane, toluidine blue, DEAE-cellulose, o-dianisidine dihydrochloride, potassium phosphate monobasic, potassium phosphate dibasic, hexadecyltrimethylammonium bromide (HTAB), cystein, papain, and bovine serum albumin were purchased from Sigma (St. Louis, MO, USA); dexamethasone was purchased from Aché (Guarulhos, SP, Brazil); morphine sulfate Dimorf ${ }^{\circledR}$ was purchased from Cristália (Itapira, SP, Brazil); gelatin was purchased from Oxoid, Ltd., (England); and ethylenediaminetetraacetic acid (EDTA), formaldehyde, glacial acetic acid, and hydrate of chloral were purchased from VETEC Química Farm. Ltda., (SP, Brazil). The drugs and samples were solubilized in $0.9 \%$ sterile $\mathrm{NaCl}$ (saline). The enzymatic kits used for evaluation of systemic toxicity were purchased from LABTEST (Diagnostic Tests, Brazil). All other chemicals were of analytical grade.

\section{Alga}

The red marine alga Acanthophora muscoides (Linnaeus) Bory de Saint-Vincent was collected at the Atlantic coast of Brazil (Pacheco Beach, Caucaia, Ceará). After collection, the material was cleaned of epiphytes, washed with distilled water, macerated in liquid nitrogen and stored at $-20^{\circ} \mathrm{C}$ until use. A voucher specimen (no. 46093) was deposited in the Herbarium Prisco Bezerra (EAC) in the Department of Biology, Federal University of Ceará, Brazil. 


\section{Extraction of total sulfated polysaccharides}

The total sulfated polysaccharides were extracted as described previously [14], with some modifications. Essentially, the dried tissue (5 g) was suspended in $250 \mathrm{ml}$ of $0.1 \mathrm{M}$ sodium acetate buffer ( $\mathrm{pH}$ 5.0), containing $1.0 \mathrm{~g}$ of papain, $5 \mathrm{mM}$ EDTA and $5 \mathrm{mM}$ cysteine and incubated at $60^{\circ} \mathrm{C}$ for $6 \mathrm{~h}$. The incubation mixture was then filtered by a nylon membrane and the homogenate was saved. The residue was washed with $125 \mathrm{ml}$ of distilled water, and filtered again, and the two homogenates were combined. The sulfated polysaccharides in solution were precipitated with $16 \mathrm{ml}$ of $10 \%$ cetylpyridinium chloride (CPC) solution. After $24 \mathrm{~h}$ at room temperature, the mixture was centrifuged at $2,560 \times \mathrm{g}$ for $20 \mathrm{~min}$ at $5^{\circ} \mathrm{C}$. The sulfated polysaccharides in the pellet were washed with $500 \mathrm{ml}$ of $0.05 \%$ CPC solution, dissolved with $100 \mathrm{ml}$ of a $2 \mathrm{M} \mathrm{NaCl}$-ethanol (100:15, v/v) mixture and precipitated with $200 \mathrm{ml}$ of absolute ethanol. After $24 \mathrm{~h}$ at $4^{\circ} \mathrm{C}$, the precipitate was collected by centrifugation $\left(2,560 \times \mathrm{g}\right.$ for $20 \mathrm{~min}$ at $\left.5^{\circ} \mathrm{C}\right)$, washed twice with $200 \mathrm{ml}$ of $80 \%$ ethanol and washed once with $150 \mathrm{ml}$ of absolute ethanol. The final precipitate was dialyzed, and freeze-dried. After these procedures, the total sulfated polysaccharides from A. muscoides (Am-TSP) were obtained.

\section{Fractionation by ion-exchange chromatography}

The Am-TSP $(30 \mathrm{mg})$ were dissolved in $15 \mathrm{ml}$ of $50 \mathrm{mM}$ sodium acetate buffer ( $\mathrm{pH}$ 5.0) and submitted to an ion-exchange chromatography on a DEAEcellulose column $(20.0 \times 2.0 \mathrm{~cm})$ equilibrated with the same buffer. The elution was performed by a stepwise gradient of $0-1.5 \mathrm{M} \mathrm{NaCl}$ in the same buffer. The flow rate of the column was $2.5 \mathrm{ml} / \mathrm{min}$. Fractions of $5.0 \mathrm{ml}$ were collected and assayed for the detection of the sulfated polysaccharide using the metachromatic assay with 1,9-dimethylmethylene blue [15].

\section{Chemical analyses}

The total sugar content was estimated by phenolsulfuric acid analysis using D-galactose as a standard [12]. After acid hydrolysis of the soluble polysaccharides $\left(1 \mathrm{M} \mathrm{HCl}, 110^{\circ} \mathrm{C}, 5 \mathrm{~h}\right)$, free sulfate was measured using $\mathrm{Na}_{2} \mathrm{SO}_{4}$ as standard in the gelatin-barium method [10]. The protein content was measured by binding of Coomassie Brilliant Blue G-250 using bovine serum albumin (BSA) as a standard [4].

\section{Agarose gel electrophoresis}

Sulfated polysaccharides were analyzed by agarose gel electrophoresis as described previously [8]. The samples $(\sim 15 \mu \mathrm{g})$ were applied to a $0.5 \%$ agarose gel and run for $1 \mathrm{~h}$ at $110 \mathrm{~V}$ in $0.05 \mathrm{M} \mathrm{1,3-diaminopro-}$ pane acetate ( $\mathrm{pH} 9.0)$. The sulfated polysaccharides in the gel were fixed with $0.1 \%$ HTAB. After $12 \mathrm{~h}$, the gel was dried and stained with $0.1 \%$ toluidine blue in $0.1: 5: 5$ acetic acid : ethanol $:$ distillated water solution $(\mathrm{v} / \mathrm{v} / \mathrm{v})$.

\section{Antinociceptive activity}

\section{Writhing test}

The writhing test is used for the evaluation of analgesic activity [20]. First, male mice received an injection of either AmII (1, 3 or $9 \mathrm{mg} / \mathrm{kg}$, iv) or sterile saline $(0.9 \% \mathrm{NaCl} \mathrm{w} / \mathrm{v}, i v)$. After $30 \mathrm{~min}, 0.8 \% \mathrm{v} / \mathrm{v}$ of acetic acid was injected intraperitoneally $(10 \mathrm{ml} / \mathrm{kg})$. The number of writhes, consisting of abdominal muscle contractions and hind paw extensions, occurring between 0 and $30 \mathrm{~min}$ after acetic acid injection, was recorded. Morphine $(5 \mathrm{mg} / \mathrm{kg}, s c)$, a non selective opioid agonist, or indomethacin $(5 \mathrm{mg} / \mathrm{kg}, s c)$, a nonspecific inhibitor of cyclooxygenase [27], were used as controls.

\section{Formalin test}

The formalin test, which causes a local tissue injury to the paw, has been used as a model for localized inflammatory pain [19]. Mice received an injection of either AmII $(1,3$ or $9 \mathrm{mg} / \mathrm{kg}$, iv) or sterile saline $(0.9 \% \mathrm{NaCl} \mathrm{w} / \mathrm{v}, i v)$. After $30 \mathrm{~min}, 1 \%$ aqueous formalin $(20 \mu \mathrm{l})$ was injected into the right hind paw. The amount of time that the animal spent licking the injected paw was measured during the first $5 \mathrm{~min}$ (Phase 1, direct chemical stimulation of nociceptors) and 20-25 min after formalin injection (Phase 2, inflammatory phase). Morphine $(5 \mathrm{mg} / \mathrm{kg}, s c)$ or indomethacin $(5 \mathrm{mg} / \mathrm{kg}, s c)$ were used as controls.

\section{Hot plate test}

The hot plate test also measures analgesic activity [13]. Each mouse was placed onto the heated plate $\left(51 \pm 1^{\circ} \mathrm{C}\right)$ two times, with a 30 -min inter-trial interval. The first trial familiarized the animal with the test 
procedure and the second served as the control reaction time (licking the paw or jumping). Animals showing a reaction time greater than $10 \mathrm{~s}$ were not included in subsequent analyses. Immediately after the second trial (control reaction time), mice received an injection of either sterile saline $(0.9 \% \mathrm{NaCl} \mathrm{w} / \mathrm{v}, i v)$, AmII (1, 3 or $9 \mathrm{mg} / \mathrm{kg}, i v)$, morphine $(5 \mathrm{mg} / \mathrm{kg}, s c)$ or indomethacin $(5 \mathrm{mg} / \mathrm{kg}, s c)$ and reaction times were measured at time zero ( 0 time) and 30,60 and $90 \mathrm{~min}$ after drug administration. A cut-off time of $40 \mathrm{~s}$ was used to avoid paw lesions.

\section{Anti-inflammatory activity}

\section{Carrageenan-induced rat paw edema}

One hour before injections with carrageenan $(\mathrm{Cg})$ into the right hind paw $(500 \mu \mathrm{g} / \mathrm{paw} ; 100 \mu \mathrm{l}, s c)$ rats were pretreated with either sterile saline $(0.9 \% \mathrm{NaCl} \mathrm{w} / \mathrm{v}, s c)$, AmII $(1,3$ or $9 \mathrm{mg} / \mathrm{kg}, s c)$ or dexamethasone $(1 \mathrm{mg} / \mathrm{kg}$, sc), a synthetic glucocorticoid with potent antiinflammatory and immunosuppressant properties [25]. Control animals received the same volume of sterile saline $(0.9 \% \mathrm{NaCl} \mathrm{w} / \mathrm{v}, s c)$. Paw volume was measured immediately before (zero time) the stimulus and at selected time intervals (1, 2, 3 and $4 \mathrm{~h})$ using a plethysmometer (Panlab, Spain). The results were expressed as the variation in paw volume $(\mathrm{ml})$, calculated as the difference from the basal volume (zero time) [48].

\section{Determination of myeloperoxidase activity}

Myeloperoxidase (MPO) is an enzyme found primarily in the azurophilic granules of the neutrophils and therefore has been extensively used as a biochemical marker of the granulocytes infiltration into various tissues. The extent of neutrophil accumulation in paw tissue was measured using an MPO activity assay as previously described by Bradley et al. [5]. Briefly, $50 \mathrm{mg}$ of paw tissue was homogenized in $1 \mathrm{ml}$ potassium phosphate buffer $50 \mathrm{mM}, \mathrm{pH} 6.0$, containing $0.5 \%$ HTAB, using a Polytron homogenizer (two cycles of $10 \mathrm{~s}$ ). After centrifugation at $4,000 \times \mathrm{g}$ for $7 \mathrm{~min}$, supernatant fractions were assayed for MPO activity. Samples $(7 \mu 1)$ were mixed with phosphate buffer (200 $\mu$ l) containing $1 \mathrm{mM}$ o-dianisidine dihydrochloride and $0.0005 \%$ hydrogen peroxide in a microplate. Absorbance was measured at $450 \mathrm{~nm}$, taking two readings at $60 \mathrm{~s}$ interval. Calculation of units of MPO was realized considering that $1 \mathrm{U}$ MPO $=1 \mathrm{mmol} \mathrm{H}_{2} \mathrm{O}_{2}$ split and $1 \mathrm{mmol} \mathrm{H}_{2} \mathrm{O}_{2}$ gives a change in absorbance of 1.13 $\times 10^{-2}$ (change in absorbance $=\mathrm{nm} / \mathrm{min}$ ). Results are reported as MPO units/mg of tissue.

\section{Dextran-induced rat paw edema}

Dextran $(400 \mu \mathrm{g} / \mathrm{paw}, 100 \mu \mathrm{l})$, a classical osmotic agent [23], was injected $s c$ into the right hind paws of rats. Animals were pretreated with either AmII (0.3, $1,3$ or $9 \mathrm{mg} / \mathrm{kg}, s c)$ or sterile saline $(0.9 \% \mathrm{NaCl} \mathrm{w} / \mathrm{v}$, sc) $1 \mathrm{~h}$ before stimuli. Control animals received the same volume of sterile saline $(0.9 \% \mathrm{NaCl} \mathrm{w} / \mathrm{v}, s c)$. Paw volume was measured immediately before (zero time) the stimulus and at selected time intervals following the stimulus $(0.5,1,2,3$ and $4 \mathrm{~h})$ using a plethysmometer (Panlab, Spain).

\section{Bradykinin, histamine and serotonin-induced rat paw edema}

Bradykinin $(30 \mu \mathrm{g} / \mathrm{paw}, 100 \mu \mathrm{l})$, histamine $(100 \mu \mathrm{g} /$ paw, $100 \mu \mathrm{l})$ or serotonin $(20 \mu \mathrm{g} / \mathrm{paw}, 100 \mu \mathrm{l})$ were injected $s c$ into the right hind paws of rats. Animals were pretreated with either AmII (1 mg/kg, sc) or sterile saline $(0.9 \% \mathrm{NaCl} \mathrm{w} / \mathrm{v}, s c) 1 \mathrm{~h}$ before stimuli. Control animals received the same volume of sterile saline $(0.9 \% \mathrm{NaCl} \mathrm{w} / \mathrm{v}, s c)$. Paw volume was measured immediately before (zero time) the stimulus and at selected time intervals following the stimulus $(0.5,1,2,3$ and $4 \mathrm{~h}$ ) using a plethysmometer (Panlab, Spain).

\section{Edematogenic effect}

AmII $(500 \mu \mathrm{g} / \mathrm{paw})$ was injected $(s c)$ into the right hind paws of rats $(0.1 \mathrm{ml} / 100 \mathrm{~g}$ of body mass). Control animals received the same volume of sterile saline $(0.9 \% \mathrm{NaCl} w / \mathrm{v}, s c)$. Paw volume was measured immediately before (zero time) AmII or saline injection and at selected time intervals $(1,2,3$ and $4 \mathrm{~h}$ ) using a plethysmometer (Panlab, Spain). The results were expressed as the variation in paw volume $(\mathrm{ml})$, calculated as the difference from the basal volume (zero time).

\section{Systemic evaluation of Am-TSP}

\section{Acute toxicity study}

Male and female mice received a single dose of AmTSP $(20 \mathrm{mg} / \mathrm{kg}, i p)$ or sterile saline $(0.9 \% \mathrm{NaCl} \mathrm{w} / \mathrm{v}$, 
ip). Survival rate, mucosa, eyes, hair erection, scratching or licking of paws, freezing reactions, general overall behavior, body mass and organ weight alteration were evaluated. After $48 \mathrm{~h}$, mice were sacrificed and the liver, right kidney, heart and spleen were removed and weighed.

\section{Subchronic toxicity study}

Male and female mice were treated daily with either Am-TSP $(20 \mathrm{mg} / \mathrm{kg}$, ip) or sterile saline $(0.9 \% \mathrm{NaCl}$ $\mathrm{w} / \mathrm{v}$, ip) for fourteen consecutive days. Body mass, organ weight alteration and biochemical, hematological and histopathological parameters were evaluated. After treatment, mice were anesthetized with chloral hydrate and peripheral blood was collected for analyses. For plasma biochemistry analyses, blood was centrifuged at $500 \times \mathrm{g}$ for $15 \mathrm{~min}$ after collection. The plasma samples were stored at $-80^{\circ} \mathrm{C}$ prior to use. The following plasma biochemistry parameters were evaluated using enzymatic and colorimetric tests (LABTEST): alanine transaminase (ALT), aspartate transaminase (AST), alkaline phosphatase (ALP), urea and creatinine.

Heparinized whole blood samples were applied to a fully automated analyzer (pocH 100iV DIFF Sysmex Europe GmbH, Hamburg, Germany) for the analysis of the following parameters: red blood cell count (RBC), hemoglobin concentration, hematocrit, mean corpuscular volume (MCV), mean corpuscular hemoglobin $(\mathrm{MCH})$, mean corpuscular hemoglobin concentration (MCHC), white blood cell count (WBC), platelet count and lymphocyte, monocyte and neutrophil percentages.

After sacrificing the animals, liver, right kidney, heart, spleen, thymus and lymph node were removed, weighed and fixed with formalin. The material was then dehydrated by adding increasing concentrations of ethanol (70 to $100 \%$ ) and processed for inclusion in paraffin. The resulting blocks were sliced into $5 \mu \mathrm{m}$ thick sections, stained with hematoxylin eosin and observed under a light microscope.

\section{Statistical analyses}

The data were presented as the means \pm standard errors (SEM) for six animals per group. Student $t$-test for unpaired values and one-way analysis of variance (ANOVA) followed by Bonferroni's test were performed. Values of $\mathrm{p}<0.05$ were considered to be statistically significant.
Tab. 1. Total yield and chemical analyses of sulfated polysaccharides from the red marine alga Acanthophora muscoides

\begin{tabular}{cccc}
\hline Fraction & Yield (\%) & Total galactose (\%) & Free sulfate (\%) \\
\hline Am-TSP & 11.6 & 54.0 & 31.8 \\
Aml & $28.7^{\mathrm{a}}$ & 18.5 & 2.7 \\
Amll & $54.7^{\mathrm{a}}$ & 21.8 & 26.8 \\
AmIII & $8.0^{\mathrm{a}}$ & 22.0 & 20.3 \\
\hline
\end{tabular}

a Yield expressed in relation to the Am-TSP obtained

\section{Results}

\section{Isolation of sulfated polysaccharides}

The yield of TSP from the red alga A. muscoides (Am-TSP) was $11.6 \%$ and presented a high content of both total sugar and free sulfate and trace amounts of protein content (Tab. 1). Anion-exchange chromatography on DEAE-cellulose separated the sulfated polysaccharides from the red alga $A$. muscoides into three major peaks, named as AmI, AmII and AmIII, eluted from the column with $0.5,0.75$ and $1.0 \mathrm{M} \mathrm{NaCl}$, respectively (Fig. 1A).

The fractions showed yields, total sugar and free sulfate contents of 28.7, 18.5 and 2.7\% (AmI), 54.7, 21.8 and 26.84\% (AmII) and 8.0, 22.0 and 20.3\% (AmIII), respectively. Contaminant proteins were not detected in any sample (Tab. 1). Agarose gel electrophoresis revealed that the fractions AmII and AmIII, contained single bands (Fig. 1B); therefore, they are homogeneous in charge density. The fraction AmI was not revealed due to its low content of sulfate. Subsequent experiments were performed with AmII due to its higher yield.

\section{Antinociceptive activity}

AmII (1, 3 or $9 \mathrm{mg} / \mathrm{kg}$; iv), injected $30 \mathrm{~min}$ prior to acetic acid, inhibited the writhing response by 60.0 , 64.4 and $71.3 \%$, respectively. There was no statistical difference between the doses of AmII used. Morphine or indomethacin $(5 \mathrm{mg} / \mathrm{kg}, s c)$ showed significant 98.20 and $55.70 \%$ inhibition of writhing response, respectively, as compared to saline group (Fig. 2). 


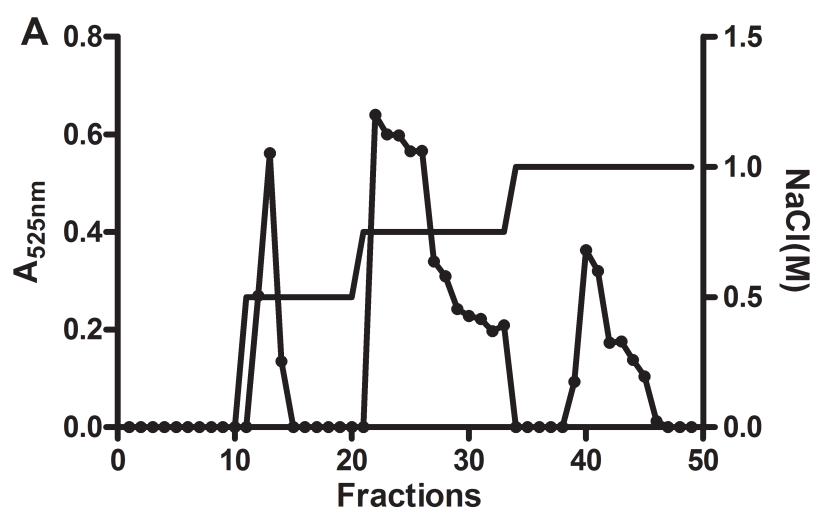

B

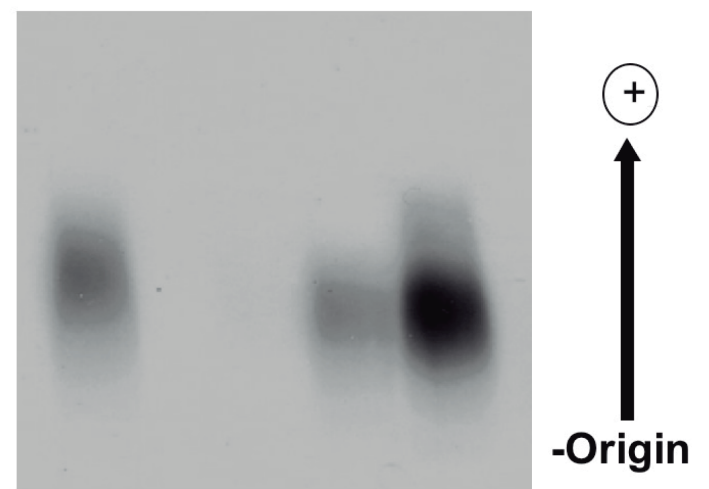

TSP Aml Amll Amlll

Fig. 1. Fractioning and agarose gel electrophoresis of sulfated polysaccharides from the red marine alga Acanthophora muscoides. (A) Fractioning of total sulfated polysaccharides from A. muscoides by ion-exchange chromatography on DEAE-cellulose. The column was developed by a stepwise gradient of $\mathrm{NaCl}(-)$. The fractions were collected from the column and assayed by metachromasia using 1,9-dimethylmethylene blue (••). (B) Agarose gel electrophoresis of sulfated polysaccharides. Samples ( 20 $\mu \mathrm{g}$ of each) of total sulfated polysaccharides (Am-TSP) and fractions Aml $(0.5 \mathrm{M})$, Amll $(0.75 \mathrm{M})$ and Amlll $(1.0 \mathrm{M})$ were stained with toluidine blue, as described under methods

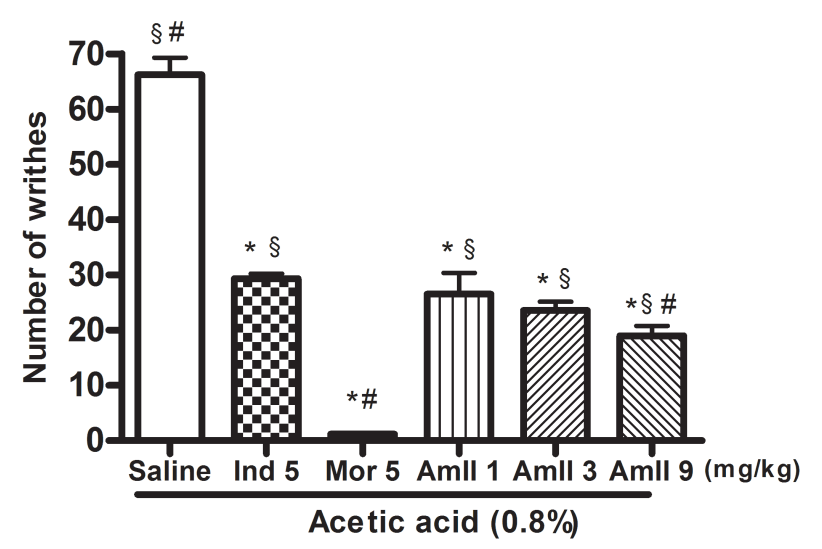

Fig. 2. Effect of administration of Amll on the writhing response induced by acetic acid. Mice received sterile saline (iv) or Amll (1, 3 or 9 mg/kg, iv), morphine ( $5 \mathrm{mg} / \mathrm{kg}, \mathrm{sc}$ ) or indomethacin (5 mg/kg, sc) $30 \mathrm{~min}$ before stimulus. Data were expressed as the means $\pm \operatorname{SEM}(n=6) .{ }^{*} p<0.05$ indicates significant difference from the saline group, $\# p<0.05$ indicates significant difference from indomethacin and $\S p<0.05$ indicates significant difference from morphine (ANOVA; Bonferroni's test)

AmII (1, 3 or $9 \mathrm{mg} / \mathrm{kg}, i v)$, injected $30 \mathrm{~min}$ prior to formalin, reduced the licking time only in the second phase (inflammatory) of the test by $87.36,88.44$ and $93.10 \%$, respectively. There was no statistical difference between the doses of AmII used. Indomethacin inhibited the second phase by $63.28 \%$. Morphine significantly reduced the formalin response in both phases $(92.0 \%$ in the first phase and $91.6 \%$ in the second phase) (Fig. 3).
In the hot plate test, neither AmII $(1,3$ or $9 \mathrm{mg} / \mathrm{kg}$, $i v)$ nor indomethacin induced significant antinociceptive effects on reaction time during 90 min of observation. Morphine induced analgesia, as shown by the delays in reaction time of $34.1 \pm 2.8,29.8 \pm 1.4$ and 23.1 $\pm 2.7 \mathrm{~s}$ at the 30,60 and $90 \mathrm{~min}$ time points, respectively (Tab. 2). In addition, AmII at the dose of 0.3 $\mathrm{mg} / \mathrm{kg}(i v)$ has been analyzed on acetic acid, formalin and hot plate models of nociception, but the results did not differ from the control group (data not shown).

\section{Anti-inflammatory activity}

Cg caused intense paw edema, which reached a maximum level at $3 \mathrm{~h}(0.58 \pm 0.04 \mathrm{ml})$. AmII $(1,3$ or $9 \mathrm{mg} / \mathrm{kg}, s c$ ) did not alter the occurrence of edema when compared to the control group at all time intervals (Tab. 3). Dexamethasone (1 $\mathrm{mg} / \mathrm{kg}, s c)$ inhibited the edema at all time intervals and reduced the MPO activity by $87.17 \%$. In addition, myeloperoxidase levels (MPO), a biochemical marker of neutrophils infiltration, were measured according to Bradley et al. [5]. AmII $(1,3$ or $9 \mathrm{mg} / \mathrm{kg}, s c)$ did not reduce the MPO activity in the paw tissue while dexamethasone reduced the MPO activity by $87.17 \%$ (Fig. 4).

Dextran caused intense paw edema, which reached a maximum level at $0.5 \mathrm{~h}(0.55 \pm 0.02 \mathrm{ml})$ after administration and decreased over the subsequent hours. AmII $(1,3$ or $9 \mathrm{mg} / \mathrm{kg}, s c)$ reduced the occurrence of edema by $60.00,63.64$ and $65.46 \%$, respectively, at 


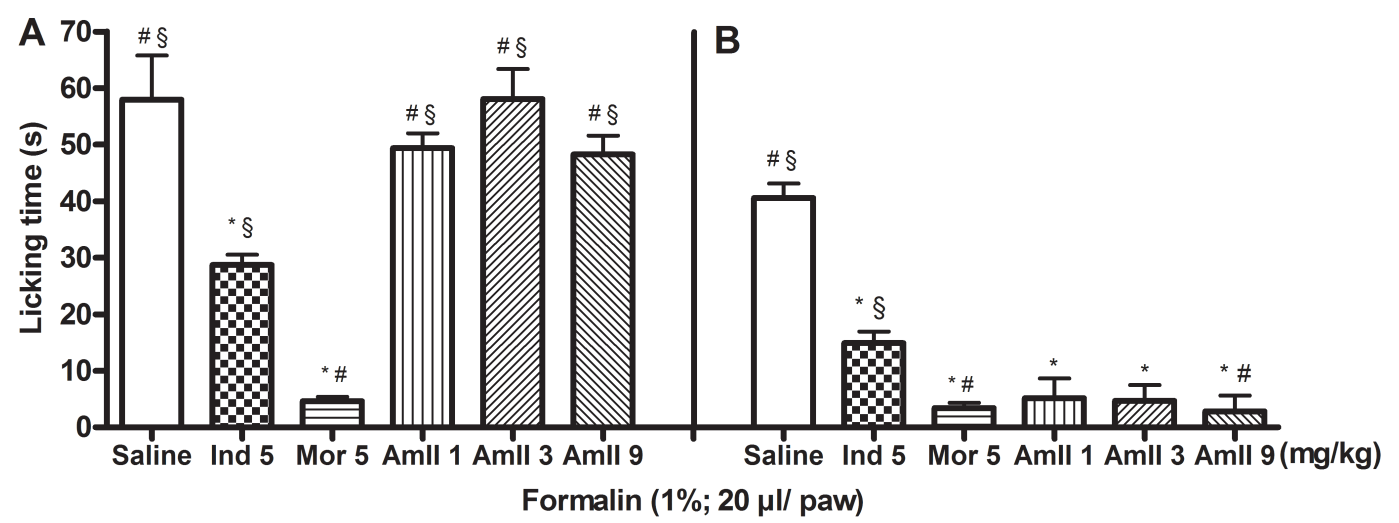

Fig. 3. Effect of Amll on formalin test in mice. The licking time spent was determined during the first 5 min ( $1^{\text {st }}$ phase; panel A), and during 20-25 min ( $2^{\text {nd }}$ phase; panel B) after $1 \%$ formalin injection in mice. Sterile saline (iv), Amll (1, 3 or 9 mg/kg, iv), morphine (5 mg/kg, sc) or indomethacin $(5 \mathrm{mg} / \mathrm{kg}, s c)$ were given $30 \mathrm{~min}$ before stimulus. Data were expressed as the means $\pm S E M(n=6)$. ${ }^{*} p<0.05$ indicates significant difference from the saline group, \# $p<0.05$ indicates significant difference from indomethacin and $\S p<0.05$ indicates significant difference from morphine (ANOVA; Bonferroni's test)

Tab. 2. Effect of Amll in reaction times (s) in the hot plate test. Mice received sterile saline, Amll, morphine or indomethacin 30 min before the stimulus

\begin{tabular}{lcccc}
\hline & \multicolumn{4}{c}{ Reaction time $(\mathrm{s})$} \\
\cline { 2 - 4 } Experimental groups & $0 \mathrm{~min}$ & $30 \mathrm{~min}$ & $60 \mathrm{~min}$ & $90 \mathrm{~min}$ \\
\hline Saline (iv) & $7.33 \pm 0.56$ & $4.67 \pm 0.80$ & $6.33 \pm 0.88$ & $6.50 \pm 1.31$ \\
Morphine (5 mg/kg; $s c)$ & $10.20 \pm 0.7$ & $34.10 \pm 2.8^{\star}$ & $29.80 \pm 1.4^{\star}$ & $23.10 \pm 2.7^{\star}$ \\
Indomethacin (5 mg/kg; $s c)$ & $8.10 \pm 1.00$ & $6.70 \pm 1.00$ & $4.80 \pm 0.8$ & $4.10 \pm 0.60$ \\
Amll (1 mg/kg; iv) & $4.33 \pm 0.88$ & $4.67 \pm 0.80$ & $3.66 \pm 0.88$ & $5.33 \pm 0.88$ \\
Amll (3 mg/kg; iv) & $5.66 \pm 1.08$ & $2.33 \pm 0.76$ & $5.66 \pm 0.84$ & $3.50 \pm 0.99$ \\
Amll (9 mg/kg; iv) & $7.00 \pm 0.86$ & $3.66 \pm 0.95$ & $5.17 \pm 1.08$ & $4.50 \pm 0.67$ \\
\hline
\end{tabular}

Data were expressed as means \pm SEM $(n=6) .{ }^{*} p<0.05$ indicates significant difference from the saline group (ANOVA; Bonferroni's test)

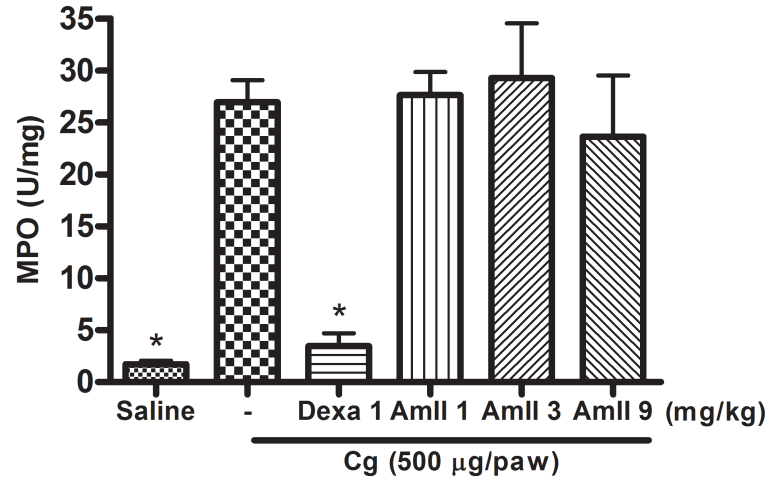

Fig. 4. Myeloperoxidase (MPO) activity in the supernatant of paw tissue from rats submitted to carrageenan $(\mathrm{Cg})$-induced paw edema. Amll (1, 3 or $9 \mathrm{mg} / \mathrm{kg}, s c)$, dexamethasone (Dexa; $1 \mathrm{mg} / \mathrm{kg}, s c$ ) or sterile saline (sc) were given $1 \mathrm{~h}$ before stimulus. MPO activity was expressed as units per mg of tissue. Data were expressed as the means $\pm \operatorname{SEM}(n=6)$. ${ }^{*} p<0.05$ indicates significant difference from the carrageenan group (ANOVA; Bonferroni's test) half hour interval (Tab. 4). In addition, AmII at the dose of $0.3 \mathrm{mg} / \mathrm{kg}(s c)$ has been analyzed on both the $\mathrm{Cg}$ and dextran-induced paw edemas, however, the results did not differ from the control group (data not shown). As the doses of 1,3 and $9 \mathrm{mg} / \mathrm{kg}(s c)$ had similar effects, the dose of $1 \mathrm{mg} / \mathrm{kg}(s c)$ was used in the subsequent assay, in which AmII $(1 \mathrm{mg} / \mathrm{kg}, s c)$ reduced the paw edemas elicited by histamine and serotonin by 33.33 and $16.67 \%$, respectively, at one hour interval, but was ineffective on bradykinin-induced paw edema (Tab. 5).

\section{Evaluation of Amll edematogenic effect}

Local injection of AmII $(500 \mu \mathrm{g}, s c)$ into the paw did not induce paw edema when compared to control ani- 
Tab. 3. Effect of Amll on carrageenan-induced rat paw edema (Cg; $500 \mu \mathrm{g} / \mathrm{paw})$. Animals received sterile saline, Amll or dexamethasone (Dexa) $1 \mathrm{~h}$ before receiving an injection of $\mathrm{Cg}(500 \mu \mathrm{g} / \mathrm{paw})$. Another group received only sterile saline (sc) in the paw

\begin{tabular}{lcccc}
\hline & \multicolumn{4}{c}{ Paw edema $(\mathrm{ml})$} \\
\cline { 2 - 4 } Experimental groups & $1 \mathrm{~h}$ & $2 \mathrm{~h}$ & $3 \mathrm{~h}$ \\
\hline Saline (sc) & $0.01 \pm 0.01^{*}$ & $0.06 \pm 0.02^{*}$ & $0.01 \pm 0.01^{*}$ & $0.00 \pm 0.00^{*}$ \\
Cg + Saline (sc) & $0.25 \pm 0.05$ & $0.49 \pm 0.06$ & $0.58 \pm 0.04$ & $0.35 \pm 0.04$ \\
Cg + Dexa (1 mg/kg; sc) & $0.17 \pm 0.02$ & $0.11 \pm 0.04^{*}$ & $0.09 \pm 0.05^{\star}$ & $0.08 \pm 0.04^{*}$ \\
Cg + Amll (1 mg/kg; sc) & $0.17 \pm 0.03$ & $0.37 \pm 0.07$ & $0.48 \pm 0.03$ & $0.29 \pm 0.05$ \\
Cg + Amll (3 mg/kg; sc) & $0.14 \pm 0.02$ & $0.37 \pm 0.07$ & $0.43 \pm 0.06$ & $0.23 \pm 0.04$ \\
Cg + Amll (9 mg/kg; $s c)$ & $0.20 \pm 0.04$ & $0.39 \pm 0.04$ & $0.56 \pm 0.03$ & $0.34 \pm 0.06$ \\
\hline
\end{tabular}

Data are expressed as the means $\pm \operatorname{SEM}(n=6) .{ }^{*} p<0.05$ indicates significant difference from the carrageenan group (ANOVA; Bonferroni's test)

Tab. 4. Effect of Amll on dextran-induced rat paw edema ( $400 \mu \mathrm{g} / \mathrm{paw})$. Animals received sterile saline, Amll ( 1 , 3 or $9 \mathrm{mg} / \mathrm{kg}, \mathrm{sc})$ or $1 \mathrm{~h}$ before receiving an injection of dextran $(400 \mu \mathrm{g} / \mathrm{paw}, \mathrm{sc})$. Another group received only sterile saline (sc) in the paw

\begin{tabular}{lccccc}
\hline \multirow{2}{*}{ Experimental groups } & \multicolumn{5}{c}{ Paw edema $(\mathrm{ml})$} \\
\cline { 2 - 6 } & $0.5 \mathrm{~h}$ & $1 \mathrm{~h}$ & $2 \mathrm{~h}$ & $3 \mathrm{~h}$ & $4 \mathrm{~h}$ \\
\hline Saline (sc) & $0.01 \pm 0.01^{*}$ & $0.06 \pm 0.02^{*}$ & $0.01 \pm 0.01^{\star}$ & $0.00 \pm 0.00^{\star}$ & $0.00 \pm 0.00^{\star}$ \\
Dextran + Saline (sc) & $0.55 \pm 0.02$ & $0.37 \pm 0.04$ & $0.18 \pm 0.07$ & $0.18 \pm 0.06$ & $0.18 \pm 0.04$ \\
Dextran + Amll (1 mg/kg, sc) & $0.22 \pm 0.04^{*}$ & $0.35 \pm 0.11$ & $0.23 \pm 0.09$ & $0.24 \pm 0.1$ & $0.07 \pm 0.04$ \\
Dextran + Amll (3 mg/kg, sc) & $0.20 \pm 0.08^{\star}$ & $0.30 \pm 0.06$ & $0.23 \pm 0.06$ & $0.27 \pm 0.08$ & $0.14 \pm 0.05$ \\
Dextran + Amll (9 mg/kg, sc) & $0.19 \pm 0.10^{\star}$ & $0.18 \pm 0.06$ & $0.19 \pm 0.08$ & $0.17 \pm 0.05$ & $0.17 \pm 0.03$ \\
\hline
\end{tabular}

Data are expressed as the means $\pm \operatorname{SEM}(n=6) .{ }^{*} p<0.05$ indicates significant difference from the dextran group (ANOVA; Bonferroni's test)

Tab. 5. Effect of Amll on bradykinin, histamine or serotonin-induced rat paw edemas. Animals received sterile saline or Amll $1 \mathrm{~h}$ before receiving an injection of bradykinin $(30 \mu \mathrm{g} / \mathrm{paw}, \mathrm{sC})$, histamine $(100 \mu \mathrm{g} / \mathrm{paw}, \mathrm{sC})$ or serotonin $(20 \mu \mathrm{g} / \mathrm{paw}, \mathrm{sC})$

\begin{tabular}{|c|c|c|c|c|c|}
\hline \multirow{2}{*}{ Experimental groups } & \multicolumn{5}{|c|}{ Paw edema (ml) } \\
\hline & $0.5 \mathrm{~h}$ & $1 \mathrm{~h}$ & $2 \mathrm{~h}$ & $3 \mathrm{~h}$ & $4 \mathrm{~h}$ \\
\hline \multicolumn{6}{|l|}{ Bradykinin } \\
\hline Saline (sc) & $0.38 \pm 0.05$ & $0.49 \pm 0.04$ & $0.33 \pm 0.03$ & $0.21 \pm 0.04$ & $0.14 \pm 0.06$ \\
\hline Amll (1 mg/kg, sc) & $0.46 \pm 0.06$ & $0.48 \pm 0.05$ & $0.38 \pm 0.04$ & $0.17 \pm 0.03$ & $0.16 \pm 0.03$ \\
\hline \multicolumn{6}{|l|}{ Histamine } \\
\hline Saline (sc) & $0.38 \pm 0.06$ & $0.33 \pm 0.03$ & $0.39 \pm 0.02$ & $0.27 \pm 0.02$ & $0.21 \pm 0.02$ \\
\hline Amll (1 mg/kg, sc) & $0.34 \pm 0.03$ & $0.22 \pm 0.03^{*}$ & $0.36 \pm 0.04$ & $0.25 \pm 0.03$ & $0.15 \pm 0.02$ \\
\hline \multicolumn{6}{|l|}{ Serotonin } \\
\hline Saline (sc) & $0.61 \pm 0.08$ & $0.90 \pm 0.05$ & $0.52 \pm 0.07$ & $0.40 \pm 0.06$ & $0.30 \pm 0.07$ \\
\hline Amll $(1 \mathrm{mg} / \mathrm{kg}, s c)$ & $0.79 \pm 0.05$ & $0.75 \pm 0.05^{\star}$ & $0.50 \pm 0.05$ & $0.50 \pm 0.04$ & $0.25 \pm 0.05$ \\
\hline
\end{tabular}

Data expressed as the mean $\pm \operatorname{SEM}(n=6) .{ }^{*} p<0.05$ indicates significant difference from the saline group. Student $t$-test for unpaired values 
mals that received an injection of the same volume of sterile saline $(0.9 \% \mathrm{NaCl} \mathrm{w} / \mathrm{v}, s c)$ (Tab. 6).

\section{Systemic evaluation of Am-TSP}

Am-TSP (20 mg/kg, ip) did not produce any signs of toxicity or mortality during the experimental period of $48 \mathrm{~h}$ (data not shown). In addition, repeated injections of Am-TSP $(20 \mathrm{mg} / \mathrm{kg}$, ip $)$ over fourteen consecutive days did not alter the overall body mass and the wet weights of the liver, kidney, heart, spleen, thymus and lymph nodes. Plasmatic levels of enzymatic indicators of he- patic function (ALT and AST) did not differ from the respective controls. Plasmatic levels of creatinine, an indicator of renal function, also did not differ from the controls. There was a reduction of the levels of urea and ALP in the female group only of 55.16 and $47.15 \%$, respectively (Tab. 7). In relation to the hematological parameters there was only a slight reduction of the lymphocyte percentage and a slight increase of the neutrophil percentage in the male group (Tab. 8). However, these values were within the normal range, according to Reference Values for Laboratory Animals from Research Animal Resources, University of Minnesota [33].

Tab. 6. Edematogenic effect of Amll in rats. Animals received sterile saline or Amll (in the paw)

\begin{tabular}{|c|c|c|c|c|c|}
\hline \multirow{2}{*}{ Experimental groups } & \multicolumn{4}{|c|}{ Paw edema (ml) } & \multirow[b]{2}{*}{$4 h$} \\
\hline & $0.5 \mathrm{~h}$ & $1 \mathrm{~h}$ & $2 \mathrm{~h}$ & $3 h$ & \\
\hline Saline (sc) & $0.25 \pm 0.05$ & $0.3 \pm 0.06$ & $0.03 \pm 0.03$ & $0.00 \pm 0.00$ & $0.00 \pm 0.00$ \\
\hline Amll $(500 \mu \mathrm{g}, s c)$ & $0.2 \pm 0.03$ & $0.24 \pm 0.06$ & $0.04 \pm 0.04$ & $0.10 \pm 0.10$ & $0.00 \pm 0.00$ \\
\hline
\end{tabular}

Data were expressed as the means $\pm \operatorname{SEM}(n=6)$. ANOVA; Bonferroni's test

Tab. 7. Systemic effects of Am-TSP in mice. Animals were weighed and injected daily with Am-TSP (20 mg/kg, ip) during fourteen days. After that, animals were weighed, anesthetized and the blood samples were collected for biochemical dosage (AST, ALT, ALP, urea and creatinine). Mice were then sacrificed and the wet weights of organs were taken

\begin{tabular}{|c|c|c|c|c|}
\hline \multirow{3}{*}{ Parameters } & \multicolumn{4}{|c|}{ Treatment (ip) } \\
\hline & \multicolumn{2}{|c|}{ Males } & \multicolumn{2}{|c|}{ Females } \\
\hline & Saline & $\begin{array}{c}\text { Amll } \\
(20 \mathrm{mg} / \mathrm{kg})\end{array}$ & Saline & $\begin{array}{c}\text { Amll } \\
(20 \mathrm{mg} / \mathrm{kg})\end{array}$ \\
\hline Body mass $(\mathrm{g})$ before & $25.68 \pm 0.67$ & $22.33 \pm 0.33$ & $22.15 \pm 0.67$ & $23.67 \pm 0.42$ \\
\hline Body mass $(\mathrm{g})$ after & $29.58 \pm 0.72$ & $25.38 \pm 0.50$ & $25.17 \pm 0.60$ & $30.00 \pm 0.60$ \\
\hline Liver (g/100 g body mass) & $5.24 \pm 0.18$ & $6.14 \pm 0.14$ & $5.46 \pm 0.08$ & $6.16 \pm 0.17$ \\
\hline Kidney (g/100 g body mass) & $0.77 \pm 0.03$ & $0.86 \pm 0.02$ & $0.86 \pm 0.14$ & $1.04 \pm 0.02$ \\
\hline Heart (g/100 g body mass) & $0.72 \pm 0.03$ & $0.67 \pm 0.02$ & $0.81 \pm 0.03$ & $0.83 \pm 0.05$ \\
\hline Spleen (g/100 g body mass) & $0.42 \pm 0.04$ & $0.46 \pm 0.03$ & $0.49 \pm 0.03$ & $0.62 \pm 0.04$ \\
\hline Thymus (g/100 g body mass) & $0.30 \pm 0.03$ & $0.30 \pm 0.03$ & $0.41 \pm 0.02$ & $0.52 \pm 0.07$ \\
\hline Lymph node (g/100 g body mass) & $0.22 \pm 0.02$ & $0.19 \pm 0.03$ & $0.22 \pm 0.02$ & $0.27 \pm 0.07$ \\
\hline AST (UI/I) & $76.57 \pm 5.49$ & $76.42 \pm 4.16$ & $51.60 \pm 10.08$ & $65.39 \pm 6.60$ \\
\hline ALT (UI/I) & $31.00 \pm 1.56$ & $39.92 \pm 4.27$ & $45.86 \pm 6.47$ & $36.64 \pm 2.88$ \\
\hline ALP (UI/I) & $104.80 \pm 4.24$ & $100.80 \pm 11.54$ & $87.32 \pm 9.62$ & $37.63 \pm 5.60^{*}$ \\
\hline Urea (mg/dl) & $32.93 \pm 3.03$ & $29.37 \pm 2.78$ & $30.33 \pm 1.83$ & $17.61 \pm 1.05^{\star}$ \\
\hline Creatinine (UI/I) & $2.18 \pm 0.28$ & $1.52 \pm 0.13$ & $1.75 \pm 0.21$ & $1.80 \pm 0.17$ \\
\hline
\end{tabular}

Data are expressed as the mean \pm SEM $(n=6)$. ${ }^{*} p<0.05$ indicates significant difference from the saline group. Student t-test for unpaired values 
Fig. 5. Histopathological analyses of organs from mice after subchronic treatment with Am-TSP $(20 \mathrm{mg} / \mathrm{kg}$, ip) for fourteen days. Saline groups: spleen $(\mathbf{A})$, heart $(\mathbf{B})$, thymus $(\mathbf{C})$, liver (G), lymph nodes (H) and kidney (I) Am-TSP groups: spleen (D), heart (E) thymus $(\mathbf{F})$, liver $(\mathbf{J})$, lymph nodes $(\mathbf{K})$ and kidney (L). The organs were fixed with paraformaldehyde and stained with hematoxylin and eosin. Analyses of the cross sections revealed no difference among the spleens, the thymus and the lymph nodes from AmTSP groups compared to saline groups. Analyses of Am-TSP groups revealed microvesicular degeneration of the cardiac fibers (E), mild vacuolar degeneration in the livers $(\mathbf{J})$, mixed inflammatory infiltrate only in perirenal fat (L) (arrows). There was no difference between males and females in any of the groups. The tissue sections were observed under light microscope at $400 \times$. Scale bars represent $50 \mu \mathrm{m}$
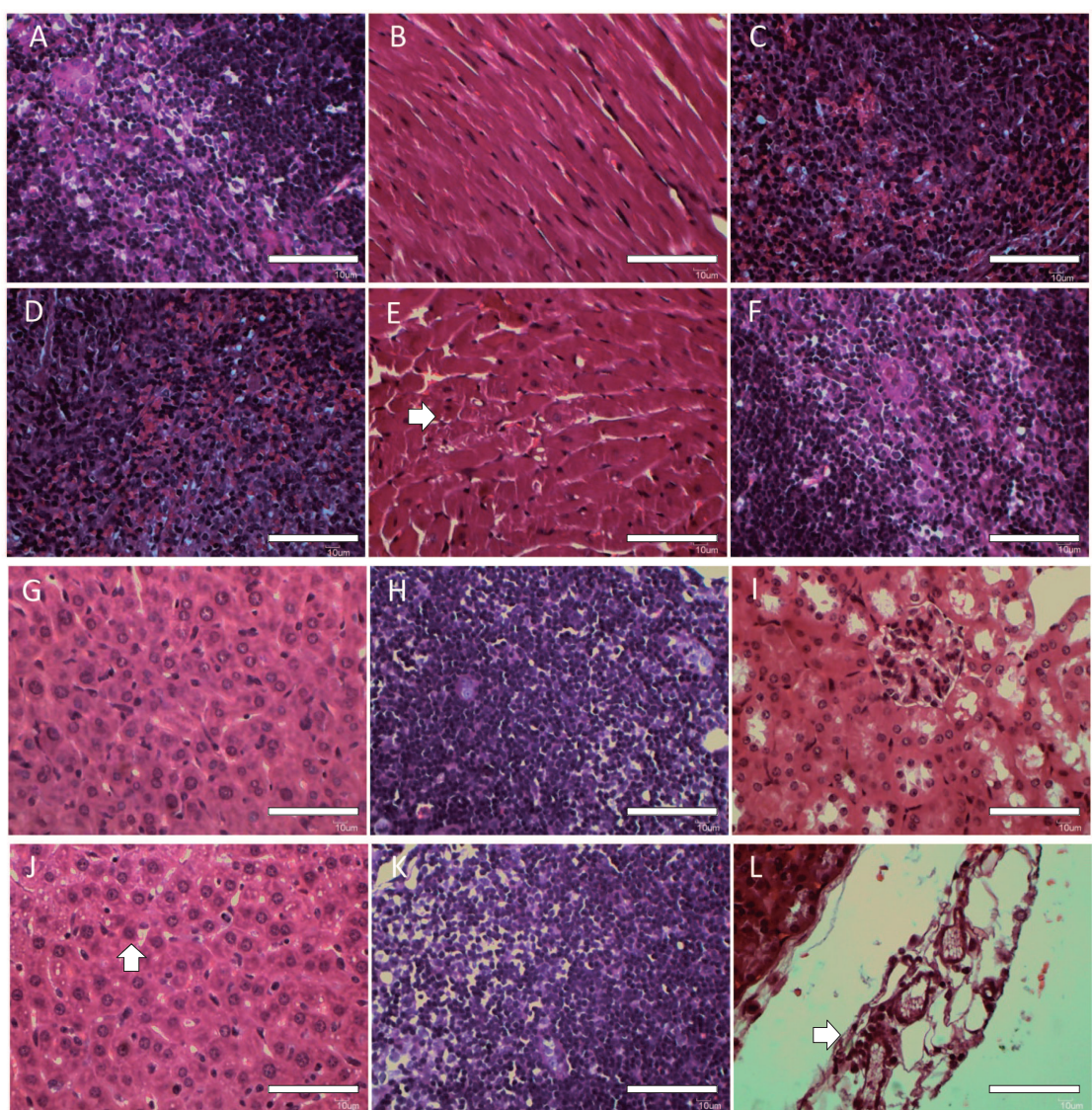

Tab. 8. Hematological parameters of mice. Animals were weighed and injected once daily with Am-TSP (20 mg/kg, ip) during fourteen days

\begin{tabular}{|c|c|c|c|c|}
\hline \multirow{3}{*}{ Parameters } & \multicolumn{4}{|c|}{ Treatment (ip) } \\
\hline & \multicolumn{2}{|c|}{ Males } & \multicolumn{2}{|c|}{ Females } \\
\hline & Saline & $\begin{array}{c}\text { Amll } \\
(20 \mathrm{mg} / \mathrm{kg})\end{array}$ & Saline & $\begin{array}{c}\text { Amll } \\
(20 \text { mg/kg) }\end{array}$ \\
\hline RBC $(106 / \mu l)$ & $8.30 \pm 0.80$ & $8.89 \pm 0.14$ & $8.22 \pm 0.24$ & $9.45 \pm 0.18$ \\
\hline Hemoglobin (g/dl) & $14.62 \pm 0.44$ & $14.05 \pm 0.24$ & $13.18 \pm 0.36$ & $15.12 \pm 0.16$ \\
\hline Hematocrit (\%) & $43.58 \pm 2.72$ & $44.07 \pm 0.66$ & $40.78 \pm 1.37$ & $46.87 \pm 0.83$ \\
\hline $\operatorname{MCV}(f \mid)$ & $228.2 \pm 176.6$ & $49.60 \pm 0.53$ & $49.60 \pm 0.43$ & $49.57 \pm 0.78$ \\
\hline $\mathrm{MCH}(\mathrm{pg})$ & $29.03 \pm 12.97$ & $15.80 \pm 0.20$ & $16.05 \pm 0.18$ & $16.00 \pm 0.19$ \\
\hline $\mathrm{MCHC}(\mathrm{g} / \mathrm{dl})$ & $25.92 \pm 5.19$ & $31.88 \pm 0.21$ & $32.35 \pm 0.29$ & $32.27 \pm 0.29$ \\
\hline 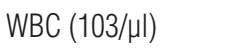 & $10.77 \pm 6.80$ & $4.97 \pm 0.82$ & $2.08 \pm 0.36$ & $4.86 \pm 1.07$ \\
\hline Lymphocytes (\%) & $89.43 \pm 1.47$ & $74.48 \pm 4.35^{\star}$ & $81.62 \pm 1.98$ & $80.34 \pm 1.72$ \\
\hline Monocytes (\%) & $0.0 \pm 0.0$ & $0.0 \pm 0.0$ & $0.0 \pm 0.0$ & $0.0 \pm 0.0$ \\
\hline Neutrophils (\%) & $10.57 \pm 1.47$ & $26.57 \pm 4.29^{\star}$ & $18.27 \pm 2.01$ & $19.66 \pm 1.72$ \\
\hline Platelets $(103 / \mu \mathrm{l})$ & $720.9 \pm 160.5$ & $995.2 \pm 203.1$ & $699.5 \pm 92.64$ & $827.2 \pm 134.8$ \\
\hline
\end{tabular}

Data are expressed as the mean \pm SEM $(n=6) .{ }^{*} p<0.05$ indicates significant difference from the saline group. Student $t$-test for unpaired values 
Histopathological analyses of the spleen, thymus and lymph nodes removed from animals treated with repeated injections of Am-TSP $(20 \mathrm{mg} / \mathrm{kg}$, ip) did not reveal any damage to the tissues. Mild sparse myocyte microvesicular degeneration was noted in the heart. The liver displayed discrete vacuolar degeneration of hepatocytes, and perirenal fat showed mild mixed inflammatory cell infiltration (Fig. 5). There were no significant lesions in the organs analyzed; the mild histological changes that were previously noted are hypothesized to be reversible. Therefore, there were no consistent signs of systemic damage.

\section{Discussion}

This study is the first report of the isolation and pharmacological activities of a sulfated polysaccharide from the red marine alga $A$. muscoides, which presented antinociceptive and anti-inflammatory effects. The intravenous and subcutaneous routes of administrations have been selected to allow a rapid systemic response sulfated polysaccharide. They have also been chosen based on previous articles evaluating the biological activities of other sulfated polysaccharides $[1,39,40]$. In addition, the sulfates polysaccharides from marine algae are considered as dietary fiber since they are usually resistant to human digestive tract enzymes and they are not absorbed after oral administration $[17,30]$. Therefore, the oral administration was not used.

The antinociceptive activity was initially evaluated by an acetic acid-induced writhing response. This test is a typical model of inflammatory pain that is widely used to screen for new agents with peripheral analgesic and anti-inflammatory properties [21, 44]. The nociceptive activity of acetic acid is associated with the release of inflammatory mediators, such as prostaglandins, sympathomimetic amines and several cytokines, including IL-1 $\beta$, TNF- $\alpha$ and IL-8 from resident peritoneal macrophages and mast cells [36].

In the present study, AmII decreased the number of acetic acid-induced abdominal constrictions (Fig. 2). The mechanism of its action may be through the inhibition of the release of endogenous substances that excite pain nerve endings. Even though there are few reports of antinociceptive sulfated polysaccharides from the red marine algae, the polysaccharides isolated from Bryothamnion triquetrum, B. seaforthii,
Champia feldmannii, Gracilaria cornea and Solieria filiformis also inhibited the writhing response of mice after the injection of acetic acid [1, 2, 7, 45, 46].

To further evaluate the AmII antinociceptive properties the model of formalin-induced nociception was also used. The injection of formalin produces a biphasic behavioral response. The first phase is characterized by neurogenic pain caused by the direct chemical stimulation of nociceptors. The second phase is characterized by inflammatory pain triggered by a combination of stimuli, including inflammation of the peripheral tissues and mechanisms of central sensitization [42]. Inflammatory mediators such as substance $P$ and bradykinin participate in the early phase, while histamine, serotonin, prostaglandins, nitric oxide and bradykinin, released from damaged cells, are involved in the late phase [24]. Drugs that act primarily on the central nervous system inhibit both phases equally, while peripherally acting drugs, like nonsteroidal anti-inflammatory drugs and corticosteroids, inhibit the late phase [3]. In this test, AmII showed a greater inhibition in the second phase than the first phase (Fig. 3), suggesting that its antinociceptive effect is related to inflammatory pain [42].

In order to confirm the absence of central antinociceptive action of AmII, the hot plate test was performed. It is well established that this test is an appropriate means of measuring the specific central antinociceptive activity in which opioid agents exert their analgesic effects via supra spinal and spinal receptors $[29,34]$. This method, however, is insensitive to nonsteroidal analgesics like cyclooxygenase inhibitors [21]. AmII did not alter the latency time for reaction responses (Tab. 2), indicating that the antinociceptive action of AmII occurs via a peripheral rather than a central-acting mechanism [29]. Similarly, the sulfated polysaccharide from S. filiformis also presented peripheral antinociceptive effect at the same doses [1].

Because our results suggested that the antinociceptive effect of AmII is related to inflammatory pain, we evaluated its properties in models of acute inflammation. Initially, AmII was tested using the Cg-induced rat paw edema test, a temporal and multimediated phenomenon, involving the participation of a diversity of mediators. Following the increase in vascular permeability, there is cell infiltration, mainly of neutrophils, that contributes to the inflammatory response $[9,33]$. The myeloperoxidase tissue levels are a wellstandardized marker of neutrophil infiltration in tis- 
sue, and they have been clearly shown to correlate with the disease severity [33].

AmII reduced neither the Cg-induced paw edema (Tab. 3) nor the MPO activity (Fig. 4) in the paw tissue. However, AmII was able to inhibit the dextraninduced paw edema, which is characterized by a different mechanism (Tab. 4). Dextran is a pro-inflammatory agent that increases vascular permeability by releasing vasoactive amines, such as histamine, serotonin and bradykinin, causing an osmotic edema, with low levels of protein and neutrophils [23].

Based on these results, it is possible to suggest that the anti-inflammatory action of AmII is associated to the inhibition of vascular events [40]. To confirm this hypothesis, histamine, serotonin and bradykinininduced paw edemas were performed. AmII did not inhibit the bradykinin-induced paw edema, but inhibited histamine and serotonin-induced paw edemas (Tab. 5). Interestingly, AmII exhibited its most potent inhibitory effect on the second phase of the formalin (Fig. 3), which is characterized by the involvement of histamine $\mathrm{H} 1$ receptors [31] and on the histamineinduced paw edema (Tab. 5).

Sulfated polysaccharides obtained from different species of red marine algae have presented marked differences in their pharmacological activities. The sulfated polysaccharides from Gelidium crinale strongly inhibited the dextran and histamine-induced paw edemas; slightly inhibited the Cg-induced paw edemas and did not influence the serotonin or the bradykinin edemas [40]. Differently, the sulfated polysaccharides from Gracilaria birdiae and G. cornea inhibited both the dextran and $\mathrm{Cg}$-induced paw edemas $[7,43]$. Herein, we demonstrated that AmII did not present inhibitory effects in the $\mathrm{Cg}$-induced edema, but reduced dextran, histamine and serotonin-induced paw edemas (Tabs. 3, 4 and 5).

In order to verify a possible edematogenic effect of AmII, we used a local route of administration. However, local injection of AmII $(2 \mathrm{mg} / \mathrm{kg}, s c)$ did not evoke paw edema (Tab. 6). These vary in the literature, which report that some sulfated polysaccharides from red marine algae are edematogenic. It has been demonstrated that the local administration of the sulfated polysaccharides isolated from C. feldmannii evoked a pro-inflammatory response at all doses tested $(0.1,0.3$ or $0.9 \mathrm{mg} / \mathrm{kg})$. This response was suggested to depend upon the release of primary cytokines, prostaglandins and histamines [2]. The sulfated polysaccharide from $S$. filiformis also caused paw edema by local injection, which involved cyclooxyge- nase enzymes, prostaglandins, nitric oxide and the primary cytokines IL-1 and TNF- $\alpha$ [1].

Additionally, this study evaluated the integrity of heart, liver, kidneys, spleen, thymus and lymph node of mice subjected to Am-TSP treatment in a subchronic toxicity assay using biochemical, hematological and histopathological parameters. Animals did not present any consistent signs of systemic damage (Fig. 5, Tabs. 7 and 8). It has been reported that sulfated polysaccharides from other marine algae were considered safe on toxicological evaluations [1, 2, 7, 38, 39, 40, 43].

In summary, our work describes antinociceptive and anti-inflammatory activities of a sulfated polysaccharidic fraction from the red marine alga Acanthophora muscoides. Additionally, the total sulfated polysaccharides did not present any consistent signs of systemic toxicity. Further studies aiming to elucidate the underlying molecular mechanisms of action of the antinociceptive and anti-inflammatory effects of sulfated polysaccharides from marine red algae might to be performed.

\section{Acknowledgments:}

This work was supported by grants from Conselho Nacional de Desenvolvimento Científico e tecnológico (CNPq), Coordenação de Aperfeiçoamento de Pessoal de Nível Superior (CAPES), Fundação Cearense de Apoio ao Desenvolvimento Científico e Tecnológico (FUNCAP) and Programa Rede Nordeste de Biotecnologia (RENORBIO). We thank Dr. Ana de Fátima Fontenele Urano Carvalho from the Department of Biology of the Federal University of Ceará for the use of an automated hematology analyzer. We thank Dr. Ana Cecília Menezes Fortes for her helpful assistance in the identification of the botanical specie of the marine alga. We thank Ângela Magalhães Vieira for her technical assistance. Benevides, N.M.B is a senior investigator of CNPq/Brazil.

\section{References:}

1. Araújo IWF, Vanderlei ESO, Rodrigues JAG, Coura CO, Quinderé ALG, Fontes BP, Queiroz INL et al.: Effects of a sulfated polysaccharide isolated from the red seaweed Solieria filiformis on models of nociception and inflammation. Carbohydr Polym, 2011, 86, 1207-1215.

2. Assreuy AMS, Gomes DM, Silva MSJ, Torres VM, Siqueira RCL, Pires AFP, Criddle DN et al.: Biological effects of a sulfated-polysaccharide isolated from the marine red algae Champia feldmannii. Biol Pharm Bull, 2008, 31, 691-695.

3. Bitencourt FS, Figueiredo JG, Mota MRL, Bezerra CCR, Silvestre P, Vale MR, Nascimento KS et al.: Antinociceptive and anti-inflammatory effects of a mucinbinding agglutinin isolated from the red marine alga 
Hypnea cervicornis. Naunyn-Schmiedeberg's Arch Pharmacol, 2008, 377, 139-148.

4. Bradford MM: A rapid and sensitive method for the quantitation of microgram quantities of protein utilizing the principle of protein-dye binding. Anal Biochem, 1976, 722, 248-254.

5. Bradley PP, Priebat DA, Christensen RD, Rothstein G: Measurement of cutaneous inflammation: estimation of neutrophils content with an enzyme marker. J Invest Dermatol, 1982, 78, 206-209.

6. Costa LS, Fidelis GP, Cordeiro SL, Oliveira RM, Sabry DA, Câmara RBG, Nobre LTDB et al.: Biological activities of sulfated polysaccharides from tropical seaweeds. Biomed Pharmacother, 2010, 64, 21-28.

7. Coura CO, Araújo IWF, Vanderlei ESO, Rodrigues JAG, Quinderé ALG, Fontes BP, Queiroz INL et al.: Antinociceptive and anti-inflammatory activities of sulphated polysaccharides from the red seaweed Gracilaria cornea, 2012, 110, 335-341.

8. Dietrich CP, Dietrich SMC: Electrophoretic behavior of acidic mucopolysaccharides in diamine buffers. Anal Biochem, 1976, 70, 645-647.

9. DiRosa M, Giroud JP, Willoughby DA: Studies of the mediators of the acute inflammatory response induced in rats in different sites by carrageenan and turpentine. J Pathol, 1971, 104, 15-29.

10. Dodgson, KS, Price, RG: A note on the determination of the ester sulfate content of sulfated polysaccharides. Biochem J, 1962, 84, 106-110.

11. D'Orazio N, Gammone MA, Gemello E, De Girolamo M, Cusenza S, Riccioni G: Marine bioactives: pharmacological properties and potential applications against inflammatory diseases. Mar Drugs, 2012, 10, 812-833.

12. Dubois M, Gilles KA, Hamilton JK, Rebers PA, Smith F: Colorimetric method for determination of sugars and related substances. Anal Chem, 1956, 28, 350-356.

13. Eddy NB, Leimbach D: Synthetic analgesics II. Dithienylbutenyl and dithienylbutylamines. J Pharmacol Exp Ther, 1953, 107, 385-393.

14. Farias WRL, Valente AP, Pereira MS, Mourão PAS: Structure and anticoagulant activity of sulfated galactans. Isolation of a unique sulfated galactan from the red alga Botryocladia occidentalis and comparison of its anticoagulant action with that of sulfated galactans. J Biol Chem, 2000, 275, 29299-29307.

15. Farndale RW, Buttle DJ, Barrett AJ: Improved quantitation and discrimination of sulphated glycosaminoglycans by use of dimethylmethylene blue. Biochim Biophys Acta, 1986, 883, 173-177.

16. Fonseca RJC, Oliveira SMCG, Melo FR, Pereira MG, Benevides NMB, Mourão PAS: Slight differences in sulfation of algal galactans account for differences in their anticoagulant and venous antithrombotic activities. Thromb Haemost, 2008, 99, 539-545.

17. Gómez-Ordóńez E, Jiménez-Escrig A, Rupérez P: Effect of the red seaweed Mastocarpus stellatus intake on lipid metabolism and antioxidant status in healthy Wistar rats. Food Chem, 2012, 135, 806-811.

18. Hallett JM, Leitch AM, Riley NA, Duffin R, Haslett C, Rossi AG: Novel pharmacological strategies for driving inflammatory cell apoptosis and enhancing the resolution of inflammation. Trends Pharmacol Sci, 2008, 29, 250-257.

19. Hunskaar S, Hole K: The formalin test in mice: dissociation between inflammatory and non-inflammatory pain. Pain, 1987, 30, 103-114.

20. Koster R, Anderson M, De Beer EJ: Acetic acid for analgesic screening. Fed Proc, 1959, 18, 412-414.

21. Le Bars D, Gozariu M, Cadden SW: Animal models of nociception. Pharmacol Rev, 2001, 53, 597-652.

22. Lins KOAL, Bezerra DP, Alves APNN, Alencar NMN, Lima MW, Torres VM, Farias WRL et al.: Antitumor properties of a sulfated polysaccharide from the red seaweed Champia feldmannii (Diaz-Pifferer). J Appl Toxicol, 2009, 29, 20-26.

23. Lo TN, Almeida AP, Beaven MA: Dextran and carrageenin evoke different inflammatory response in rat with respect to composition of infiltrates and effect of indomethacin. J Pharmacol Exp Ther, 1982, 221, 261-267.

24. Lopes LS, Marques RB, Pereira SS, Ayres MCC, Chaves MH, Cavalheiro AJ, Vieira Júnior GM, Almeida FR: Antinociceptive effect on mice of the hydroalcoholic fraction and (-) epicatechin obtained from Combretum leprosum Mart \& Eich. Braz J Med Biol Res, 2010, 43, 1184-1192.

25. Löwenberg M, Stahn C, Hommes DW, Buttgereit F: Novel insights into mechanisms of glucocorticoid action and the development of new glucocorticoid receptor ligands. Steroids, 2008, 73, 1025-1029.

26. McCurdy CR, Scully SS: Analgesic substances derived from natural products (natureceuticals). Life Sci, 2005, 78, 476-484.

27. Meskell M, Ettarh R: Immunohistochemical localization of renal cyclooxygenase-1 expression in non-steroidal anti-inflammatory drug-treated mice. Exp Toxicol Pathol, 2011, 63, 39-42.

28. Mestechkina NM; Shcherbukhin VD: Sulfated polysaccharides and their anticoagulant activity: a review. Appl Biochem Microbiol, 2010, 46, 267-273.

29. Nemirovsky A, Chen L, Zelma V, Jurna I: The antinociceptive effect of the combination of spinal morphine with systemic morphine or buprenorphine. Anesth Analg, 2001, 93, 197-203.

30. O’Sullivan L, Murphy B, McLoughlin P, Duggan P, Lawlor PG, Hughes H, Gardiner GE: Prebiotics from marine macroalgae for human and animal health applications Mar. Drugs, 2010, 8, 2038-2064.

31. Parada CA, Tambeli CH, Cunha FQ, Ferreira SH: The major role of peripheral release of histamine and 5hydroxytryptamine in formalin-induced nociception. Neuroscience, 2001, 102, 4, 937-944.

32. Pomin VH: Structural and functional insights into sulfated galactans: a systematic review. Glycoconj J, 2010, 27, 1-12.

33. Posadas I, Bucci M, Roviezzo F, Rossi A, Parente L, Sautebin L, Cirino G: Carrageenan-induced mouse paw oedema is biphasic, age-weight dependent and displays differential nitric oxide cyclooxygenase-2 expression. Br J Pharmacol, 2004, 142, 331-338.

34. Rani S, Gupta MCG: Evaluation and comparison of antinociceptive activity of aspartame with sucrose. Pharmacol Rep, 2012, 64, 293-298. 
35. Research Animal Resources, University of Minnesota. Reference Values for Laboratory Animals: Normal hematology values. Retrieved September 24, 2012, from http://www.ahc.umn.edu/rar/refvalues.html.

36. Ribeiro RA, Vale ML, Thomazzi SM, Paschoalato AB, Poole S, Ferreira SH, Cunha FQ: Involvement of resident macrophages and mast cells in the writhing nociceptive response induced by zymosan and acetic acid in mice. Eur J Pharmacol, 2000, 387, 111-118.

37. Rodrigues JAG, Vanderlei ESO, Quinderé ALG, Coura CO, Benevides NMB: Avaliação do potencial anticoagulante de polissacarídeos sulfatados de macroalgas marinhas. Rev Bras Eng Pesca, 2010, 5, 56-69.

38. Rodrigues JAG, Vanderlei ESO, Silva LMCM, Araújo IWF, Queiroz INL, Paula GA, Abreu TM et al.: Antinociceptive and anti-inflammatory activities of a sulfated polysaccharide isolated from the green seaweed Caulerpa cupressoides. Pharmacol Rep, 2012, 64, 282-292.

39. Siqueira RCL, Silva MSJ, Alencar DB, Pires AF, Alencar NMN, Pereira MG, Cavada BS et al.: In vivo antiinflammatory effect of a sulfated polysaccharide isolated from the marine brown algae Lobophora variegata. Pharm Biol, 2011, 49, 167-164.

40. Sousa AAS, Benevides NMB, Pires A F, Fiúza FP, Queiroz MGR, Morais TMF, Pereira MG, Assreuy AM: A report of a galactan from marine alga Gelidium crinale with in vivo anti-inflammatory and antinociceptive effects. Fund Clin Pharmacol, 2013, 27 173-180.

41. Souza BWS, Cerqueira MA, Bourbon AI, Pinheiro AC, Martins JT, Teixeira JA, Coimbra MA, Vicente AA: Chemical characterization and antioxidant activity of sulfated polysaccharide from the red seaweed Gracilaria birdiae. Food Hydrocol, 2012, 27, 287-292.

42. Tjølsen A, Berge DG, Hunskaar S, Rosland JH, Hole K: The formalin test: an evaluation of the method. Pain, 1992, 51, 5-17.
43. Vanderlei ESO, Araújo IWF, Quinderé ALG, Fontes BP, Eloy YRG, Rodrigues JAG, Silva AAR et al.: The involvement of the HO-1 pathway in the anti-inflammatory action of a sulfated polysaccharide isolated from the red seaweed Gracilaria birdiae. Inflamm Res, 2011, 60, 1121-1130.

44. Vanderlei ESO, Patoilo KKNR, Lima NA, Lima APS, Rodrigues JAG, Silva LMCM, Lima MEP et al.: Antinociceptive and anti-inflammatory activities of lectin from the marine green alga Caulerpa cupressoides. Int Immunopharmacol, 2010, 10, 1113-1118.

45. Viana GSB, Freitas ALP, Lima MML, Vieira LAP, Andrade MCH, Benevides NMB: Antinociceptive activity of sulfated carbohydrates from the red algae Bryothamnion seaforthii (Turner) Kütz. and B. triquetrum (S.G. Gmel.) M. Howe. Braz J Med Biol Res, 2002, 35, 713-722.

46. Vieira LAP, Freitas ALP, Feitosa JPA, Silva DC, Viana GSB: The alga Bryothamnion seaforthii contains carbohydrates with antinociceptive activity. Braz J Med Biol Res, 2004, 37, 1071-1079.

47. Wijesekara I, Pangestuti R, Kim SK: Biological activities and potential health benefits of sulfated polysaccharides derived from marine algae. Carbohydr Polym, 2011, 84, $14-21$.

48. Winter CA, Risley EA, Nuss GW: Carrageenin induced oedema in hind paw of rats as an assay for antiinflammatory drugs. Proc Soc Exp Biol Med, 1962, 111, 544-547.

49. Yasuhara-Bell J, Lu Y: Marine compounds and their antiviral activities. Antivir Res, 2010, 86, 231-240.

Received: February 3, 2012; in the revised form: December 10, 2012; accepted: December 28, 2012. 